\title{
Sulfide oxidation in deep Baltic Sea sediments upon oxygenation and colonization by macrofauna
}

\author{
Stefano Bonaglia ${ }^{1,2,3}$ (1) Ugo Marzocchi ${ }^{3,4,5} \cdot$ Nils Ekeroth $^{1,6} \cdot$ Volker Brüchert $^{7} \cdot$ Sven Blomqvist ${ }^{1} \cdot$ Per O. J. Hall $^{8}$
}

Received: 6 June 2019 / Accepted: 24 September 2019 / Published online: 29 October 2019

(c) The Author(s) 2019

\begin{abstract}
Coastal and shelf sediments affected by transient or long-term bottom water anoxia and sulfidic conditions undergo drastic changes in macrofauna communities and abundances. This study investigates how early colonization by two macrofaunal functional traits (epifauna vs. infauna) affects oxygen, sulfide, and $\mathrm{pH}$ dynamics in anoxic sediment upon recent bottom water oxygenation. Large mesocosms (area $900 \mathrm{~cm}^{2}$ ) with 150-m-deep Baltic Sea soft sediments were exposed to three treatments: (1) no animals; (2) addition of 170 polychaetes (Marenzelleria arctia); (3) addition of 181 amphipods (Monoporeia affinis). Porewater chemistry was investigated repeatedly by microsensor profiling over a period of 65 days. Colonization by macrofauna did not significantly deepen penetration of oxygen compared to the animal-free sediment. Bioturbation by $M$. affinis increased the volume of the oxidized, sulfide-free sediment by $66 \%$ compared to the animal-free control already after 13 days of incubation. By the end of the experiment $M$. affinis and $M$. arctia increased the oxidized sediment volume by 87 and 35\%, respectively. Higher efficiency of epifaunal amphipods in removing hydrogen sulfide than deep-burrowing polychaetes is likely due to more substantial re-oxidation of manganese and/or nitrogen compounds associated with amphipod mixing activity. Our results thus indicate that early colonization of different functional groups might have important implications for the later colonization by benthic macrofauna, meiofauna and microbial communities that benefit from oxidized and sulfide-free sediments.
\end{abstract}

Responsible Editor: M. Huettel.

Reviewed by undisclosed experts.

Stefano Bonaglia

stefano.bonaglia@su.se

1 Department of Ecology, Environment and Plant Sciences, Stockholm University, Stockholm, Sweden

2 Department of Biology, University of Southern Denmark, Odense, Denmark

3 Marine Research Institute, Klaipeda University, Klaipeda, Lithuania

4 Integrative Marine Ecology Department, Stazione Zoologica Anton Dohrn, National Institute of Marine Biology, Ecology and Biotechnology, Naples, Italy

5 Department of Biosciences, Center for Electromicrobiology, Aarhus University, Aarhus, Denmark

6 NIRAS Sweden AB, Stockholm, Sweden

7 Department of Geological Sciences, Stockholm University, Stockholm, Sweden

8 Department of Marine Sciences, University of Gothenburg, Gothenburg, Sweden

\section{Introduction}

Large amounts of settling organic matter are metabolized in coastal marine sediments due to the interaction and activity of benthic macrofauna, meiofauna and microorganisms (Middelburg et al. 1993; Kristensen 2000; Nascimento et al. 2012). Coastal sediments worldwide host abundant macrofauna populations, whose activities increase rates of solute transport, mineralization, nitrification, and denitrification in the sediment by factors of up to three (Aller 1982; Kristensen and Blackburn 1987; Aller 1994). This stimulation is due to the ability of macrofauna to ingest and redistribute particles, create and maintain burrows (bioturbation), and to ventilate burrows introducing oxygen into otherwise anoxic sediment layers (bioirrigation) (Kristensen et al. 2012). Bioturbating macrofauna may also play an important role in regulating the fate of hazardous substances by enhancing aerobic biodegradation of organic pollutants before their burial in reducing sediment compartments (Gilbert et al. 1996).

Marine coastal environments bounded by catchment areas with high anthropogenic activity, such as the central Baltic 
Sea, receive high loads of nutrients and organic matter leading to algal proliferation and eutrophication (Glibert and Burkholder 2006). When eutrophication and water stratification coexist, algal degradation in the water and in the sediment increases oxygen consumption and eventually leads to water column hypoxia and anoxia (Diaz 2001). Since higher water temperatures enhance metabolic processes and decrease oxygen solubility, ocean de-oxygenation may be further enhanced by global warming (Keeling et al. 2010). Oceanic models anticipate an expansion in the area of deadzone sediments globally in the next decades (Breitburg et al. 2018). Under these severely hypoxic or anoxic conditions, benthic aerobic processes slow down or even stop, while anaerobic processes such as denitrification, sulfate reduction and methanogenesis are promoted (Howarth 1984). In coastal and shelf sediments bacterial sulfate reduction generally dominate anaerobic rates of organic matter oxidation (Jørgensen 1982; Canfield 1989).

Microbial sulfate reducers produce sulfide, which in marine sediments usually binds to $\mathrm{Fe}(\mathrm{II})$, precipitating as amorphous $\mathrm{FeS}$ or as the more stable pyrite $\left(\mathrm{FeS}_{2}\right)$ (Berner 1984). However, in ecosystems that are characterized by very high organic loading and relatively low reactive iron such as oxygen minimum zones, the anoxic regions of the Baltic Sea and the Black Sea, free sulfide accumulates in the surface sediment or even in the bottom water (Dyrssen and Kremling 1990; Brüchert et al. 2003; Jørgensen et al. 2004). A vast body of literature shows that free hydrogen sulfide $\left(\mathrm{H}_{2} \mathrm{~S}\right)$ is toxic and leads to respiratory stress to benthic organisms already at micromolar concentrations (Völkel and Grieshaber 1992; Diaz and Rosenberg 1995; Jahn and Theede 1997). Results from a modeling experiment demonstrated that $\mathrm{H}_{2} \mathrm{~S}$ at concentrations $>14 \mu \mathrm{M}$ have negative effects on marine benthic macrofauna at population level (Vaquer-Sunyer and Duarte 2010).

Hydrogen sulfide is toxic to most benthic invertebrate organisms as it inhibits the last enzymatic reaction of the respiratory chain in the mitochondria when it binds to cytochrome aa3 (Nicholls 1975). Other inhibition mechanisms of sulfide on marine invertebrates are reviewed in Völkel and Grieshaber (1995). Epifaunal species such as the amphipod Monoporeia affinis, for example, cannot even tolerate sulfide in the low micromolar range (Sandberg-Kilpi et al. 1999). However, there are a few resistant macrofaunal species that evolved detoxification mechanisms against $\mathrm{H}_{2} \mathrm{~S}$. The Baltic clam Macoma balthica (now Limecola balthica), for example, can tolerate $\mathrm{H}_{2} \mathrm{~S}$ as it reduces gas diffusion by temporary reduction of valve opening (Jahn and Theede 1997). It has also been shown that the polychaete Marenzelleria viridis has the ability to oxidize sulfide in its mitochondria at concentrations $<50 \mu \mathrm{M}$ (Hahlbeck et al. 2000).

Long-term efforts to reduce nutrient inputs to the Baltic Sea have led to mitigation of eutrophication in the last
10 years (Andersen et al. 2017). When eutrophication and hypoxia fade, it follows sediment colonization by aerobic microorganisms and macrofauna (Stigebrandt et al. 2015). More than 3 decades ago, it was recognized that macrobenthos have a drastic effect on chemical properties of sediments, which mainly depends on the functional groups forming the benthos (Aller 1982). Diverse macrofaunal groups also have different effect on sediment oxygen dynamics and on redox profiles (Weissberger et al. 2009). Not fully understood is, however, the influence of macrofauna colonization on sediment oxygen and sulfide concentrations in previously azoic sediments. For example, it is still unclear whether epifaunal species such as amphipods, which unceasingly dig in the surficial sediment (Tuominen et al. 1999), may extend oxygen distribution and sulfidic horizon. On the contrary, certain strictly infaunal organisms may even enhance sulfide concentrations in the porewater as in Marenzelleria arctia bioturbated sediments (Bonaglia et al. 2013; Danielsson et al. 2018), possibly by increasing the rates of sulfate reduction due to their intense bioirrigation (Quintana et al. 2018).

The aim of this study is to better understand how different types of macrofauna influence oxygen, sulfide and $\mathrm{pH}$ dynamics in sediments that were naturally reducing with high sulfide concentrations, but subsequently underwent transient ( 2 weeks) and long-term ( 2 months) oxygenation. We studied two contrasting types of bioturbators: M. arctia, an invasive and opportunistic polychaete species that lives exclusively in sediment and creates J-, Y- or U-shaped burrows down to $10 \mathrm{~cm}$ into the sediment (Renz and Forster 2013; Quintana et al. 2018); and Monoporeia affinis, a very common amphipod species in the Baltic Sea, which digs in the sediment during daytime and performs nocturnal swimming in the bottom water (Hill and Elmgren 1987). These two types of invertebrates were added to oxygenated mesocosms that were containing previously anoxic Baltic Sea sediment naturally devoid of macrofauna. Measurements of porewater $\mathrm{O}_{2}, \mathrm{H}_{2} \mathrm{~S}$ and $\mathrm{pH}$ were performed at in situ temperature and salinity, thus resembling Baltic Sea sediment conditions, by means of microsensor setup over a 2-month incubation period.

\section{Methods}

\section{Sampling for sediment and macrofauna}

Intact and undisturbed sediment samples were collected from $149 \mathrm{~m}$ depth with a modified boxcorer that minimizes resuspension (Blomqvist et al. 2015) in the northwestern Baltic proper $\left(58^{\circ} 26.2095^{\prime} \mathrm{N}, 18^{\circ} 25.3751^{\prime} \mathrm{E}\right)$ in August 2012 onboard R/V Fyrbyggaren. Retrieved sediment boxes (area: $30 \times 30 \mathrm{~cm}$ ) had a sediment height of ca. $34 \mathrm{~cm}$ and a water column height of ca. $12 \mathrm{~cm}$. The water overlying sediment 
had salinity 11 , temperature $5.6{ }^{\circ} \mathrm{C}$, and concentrations of dissolved $\mathrm{O}_{2}$ measured in situ were between 0 and $8 \mu \mathrm{M}$ (Ekeroth et al. 2016a). Visual inspection indicated that the sediment was completely devoid of macrofauna. Sediment boxes were immediately transported to Askö Laboratory (Stockholm University's Baltic Sea Centre), where they were placed in a dark and temperature-controlled room at in situ temperature.

Macrofauna sampling was performed at $28 \mathrm{~m}$ depth by means of a benthic sled (Blomqvist and Lundgren 1996) in Yttre Hållsfjärden, close to Askö laboratory (Ekeroth et al. 2016a). The macroinvertebrates were extracted from the sediment by sieving with a mesh size of $0.5 \mathrm{~mm}$. From the macrofauna extract, only the amphipod Monoporeia affinis and the polychaete Marenzelleria arctia were carefully picked from the sieves with tweezers and kept in plastic containers with aerated water until the addition to the sediment boxes (see next section).

\section{Mesocosm setup}

Three boxcores (hereafter mesocosms) were incubated for this experiment and their lids were connected to external tubes, which supplied sand-filtered brackish seawater with an average particulate organic carbon (POC) concentration of $50 \mu \mathrm{g} \mathrm{L}^{-1}$ at a rate of $30 \mathrm{~mL} \mathrm{~min}^{-1}$ pumped directly from the Baltic Sea from ca. 20 m depth (Björk and Gilek 1996). This water was fully oxygenated and had salinity and temperature in the range of the water collected in situ. An outlet placed on the side of each mesocosm allowed a continuous flow of water, while an aquarium pump was placed inside each mesocosm to maintain the water conditions homogenous. Inlets, outlets and aquarium pumps were all equipped with nets, which prevented removal and unintentional import of invertebrates. The mesocosms were equipped with optical sensors (models 3830 and 4835; Aanderaa Data Instruments AS, Norway) for oxygen and temperature monitoring. Oxygen saturation ranged between 70 and $80 \%$ and temperature was kept at $5.5 \pm 1{ }^{\circ} \mathrm{C}$ (always $<8{ }^{\circ} \mathrm{C}$ ) throughout the course of the experiment (Ekeroth et al. 2016a).

Twenty days after the water aeration started, macrofauna individuals were added to each mesocosm. Under these conditions, the top dark gray fluffy sediment layer had turned into a 1-cm-thick brown sediment layer. One of the three mesocosms was left without infauna and served as control. Here, no sign of macrofauna bioturbation was detected throughout the course of the experiment. The second mesocosm received $170 \mathrm{M}$. arctia individuals, while the third mesocosm received $181 \mathrm{M}$. affinis individuals. To mirror the natural size distribution of Baltic Sea bioturbated sediments, macroinvertebrates of all sizes were randomly added to the mesocosms. The animal additions corresponded to abundances of $2020 \mathrm{M}$. arctia ind. $\mathrm{m}^{-2}$ and 2150 M. affinis ind. $\mathrm{m}^{-2}$. These densities of macroinvertebrates represent the range generally reported for Baltic Sea sediments (Villnäs and Norkko 2011; Kauppi et al. 2015). Details of the mesocosm setup and macrofauna handling are described in the companion paper by Ekeroth et al. (2016a). Converse to that study, measurements here were carried in one mesocosm per treatment. This was justified by the low heterogeneity of the sediment as confirmed by the low variability in biogeochemical processes within the sampling site (Ekeroth et al. 2016a). As a matter of fact, all nutrient fluxes strongly dependent on redox conditions, i.e., N, P and Si fluxes, were not significantly different between mesocosms before the introduction of the animals, but became significantly different right after macrofauna addition—see Fig. 3 of Ekeroth et al. (2016a).

\section{Microelectrode profiling}

Microscale depth distribution of oxygen $\left(\mathrm{O}_{2}\right)$, hydrogen sulfide $\left(\mathrm{H}_{2} \mathrm{~S}\right)$ and $\mathrm{pH}$ were measured via microsensors (Revsbech and Jørgensen 1986) in the three mesocosms, hereafter simply called (1) Control, (2) Marenzelleria, and (3) Monoporeia. The first $\mathrm{O}_{2}$ profiles were measured 1 day after the addition of the macroinvertebrates to determine if there was an immediate effect of the animal addition on $\mathrm{O}_{2}$ dynamics, while the complete microprofiling array $\left(\mathrm{O}_{2}, \mathrm{H}_{2} \mathrm{~S}\right.$ and $\mathrm{pH}$ ) was performed 13 and 65 days after the addition of the invertebrates to establish the medium- and long-term effects of animal activity on solute distribution and sediment porewater geochemistry. Microprofiles were measured directly inside each mesocosm with stirring system on using a micromanipulator (MM33, Unisense, DK) and microsensors with a tip diameter of $50 \mu \mathrm{m}$ (OX-50, H2S-50, pH-50; Unisense, DK). Oxygen profiles were carried out first and were followed by simultaneous determination of $\mathrm{H}_{2} \mathrm{~S}$ and $\mathrm{pH}$, with electrodes mounted on a double-headed micromanipulator (Unisense, DK). Three to four profiles were measured at each time for each solute in each mesocosm. A total of 70 microprofiles was carried out. For each day of measurement, $\mathrm{O}_{2}$ microelectrodes were calibrated at $\mathrm{O}_{2}$ saturation and under anoxic conditions using a two-point calibration according to the manufacturer's recommendation. Hydrogen sulfide microelectrodes were calibrated daily in fresh $\mathrm{Na}_{2} \mathrm{~S}$ solutions that were prepared with washed and cleaned $\mathrm{Na}_{2} \mathrm{~S}$ crystals in anoxic water and calibrated using the methylene blue method of Cline (1969). $\mathrm{pH}$ microelectrodes were calibrated with commercial $\mathrm{pH}$ standards of 4.00, 7.00 and 10.00 (Fisher Scientific, Gothenburg, Sweden). Concentrations of total hydrogen sulfide $\left(\Sigma \mathrm{H}_{2} \mathrm{~S}=\left[\mathrm{H}_{2} \mathrm{~S}\right]+\left[\mathrm{HS}^{-}\right]+\left[\mathrm{S}^{2-}\right]\right)$ was calculated at each depth from the measured $\mathrm{H}_{2} \mathrm{~S}$ and $\mathrm{pH}$ values (Jeroschewski et al. 1996). Diffusive sulfide flux J in the sediment was calculated from the sulfide depth profiles using Fick's first law corrected for sediment porosity: 
$J \Sigma H_{2} S=\phi D s \mathrm{~d}\left[\Sigma H_{2} S\right] / \mathrm{d} x$,

where $\phi$ is the porosity of the sediment, $D s$ is the diffusion coefficient of sulfide in the sediment, which was estimated from the porosity and the free diffusion coefficient of sulfide at infinite dilution $\left(D_{\mathrm{HS}}\right)$ using the approximation $D s=\phi^{2} \times D_{\mathrm{HS}}\left(\right.$ Ullman and Aller 1982), and d $\left[\Sigma \mathrm{H}_{2} \mathrm{~S}\right] / \mathrm{d} x$ indicates the $\mathrm{SH}_{2} \mathrm{~S}$ concentration gradient with depth in the linear interval below the sulfidic horizon. Sediment porosity ( $\mathrm{vol} / \mathrm{vol})$ was determined from dry sediment density $\left(2.65 \mathrm{~g} \mathrm{ml}^{-1}\right)$ and water content of 5-mm-thick sediment slices. Water content was quantified by loss of weight on drying each sediment slice at $60{ }^{\circ} \mathrm{C}$ until constant weight (Andrews and Bennett 1981). For the sake of conciseness, we defined the sulfidic horizon as the specific sediment depth where sediment became sulfidic (depth with $\left[\Sigma \mathrm{H}_{2} \mathrm{~S}\right]>1 \mu \mathrm{M}$ ). The OPD (oxygen penetration depth) was defined as the depth at the bottom of the oxygen profile where $\left[\mathrm{O}_{2}\right]$ was $<1 \mu \mathrm{M}$.

\section{Statistical tests and data presentation}

The effects of factors Day (Day 1, Day 13 and Day 65 for OPD; Day 13 and Day 65 for sulfidic horizon and sulfide fluxes) and Treatment (Control, Marenzelleria and Monoporeia) were tested on our dependent variables (OPD, sulfidic horizon and sulfide fluxes) by means of a two-way repeated measures ANOVA test. Normality (Shapiro-Wilk test) and equal variance (Brown-Forsythe test) were tested before running the ANOVA and these assumptions were always met. The level of significance was set to $p<0.05$. When the differences were greater than expected by chance, pairwise multiple comparison was performed (Holm-Sidak test). Statistical analyses were performed using SigmaPlot 14.0 (Systat Software, Inc., USA). Data synthesis and graphing were performed on SigmaPlot 14.0 and Origin Viewer 9.6.5 (OriginLab Corporation, USA). If not stated otherwise, measurements are reported as average mean value with associated standard error of the mean.

\section{Results}

\section{Sediment and macroinvertebrate conditions}

The upper two centimeters of sediment had very similar water contents (91-92\%) and porosities (0.96-0.97) in the control, Marenzelleria and Monoporeia treatments. The added macrofauna immediately colonized and burrowed the re-oxygenated sediment. Bioturbation by Monoporeia affinis extended to a maximum of $1.5-2.0 \mathrm{~cm}$ in the sediment, while Marenzelleria penetrated to a maximum depth of 6-7 cm (visual observations). No signs of stress or dead animals lying on the surface were detected until ca. 90 days after addition to the mesocosms. After that, several individuals of M. affinis and relatively fewer individuals of Marenzelleria were found lying on the surface of the sediment suggesting stress, likely induced by the relatively limited amount of food (i.e., phytodetritus) supplied from the flowthrough system. Thus, we interrupted the experiment after 90 days and only present results up to 65-day incubation period within which animals were alive and active.

\section{Oxygen, pH and sulfide porewater profiles}

One day after animal introduction, the oxygen penetration depth (OPD) was $0.83 \pm 0.02 \mathrm{~cm}$ in the Monoporeia mesocosm, $0.88 \pm 0.07 \mathrm{~cm}$ in the Marenzelleria mesocosm and $0.87 \pm 0.03 \mathrm{~cm}$ in the Control mesocosm (Figs. 1, 2). OPD was not significantly different between treatments $(p=0.496)$ and between the three different times $(p=0.467)$ (Table 1). After 13 days of incubation in the control mesocosm, oxygen and sulfide profiles slightly overlapped indicating the onset of an aerobic sulfide oxidation zone at $0.83 \mathrm{~cm}$ depth (Fig. 1). The $\mathrm{pH}$ decreased rapidly from the water column value of 7.5 to a minimum of 6.9 in proximity of the sulfide oxidation zone $(0.9 \mathrm{~cm}$ depth). $\mathrm{pH}$ values increased slightly with depth to a $\mathrm{pH}$ of 7.1 at $3 \mathrm{~cm}$. In the Marenzelleria treatment, oxygen penetrated $2 \mathrm{~mm}$ deeper $(1.03 \pm 0.04 \mathrm{~cm})$ compared to the control $(0.83 \pm 0.04 \mathrm{~cm})$. Overall Marenzelleria showed similar patterns to Control indicated by the overlapping oxygen and sulfide profiles and the corresponding $\mathrm{pH}$ minimum at the depth of sulfide disappearance. In the Monoporeia treatment, the OPD $(0.78 \pm 0.02 \mathrm{~cm})$ was similar to the one measured in the Control (Table 1, Fig. 2). However, sulfide and $\mathrm{pH}$ profiles showed a deepening of the sulfide oxidation zone and a development of a $0.75-\mathrm{cm}$-thick zone devoid of both oxygen and sulfide (Fig. 1). As a consequence, the sulfidic horizon was situated deeper in Monoporeia $(1.47 \pm 0.09 \mathrm{~cm})$ than in Marenzelleria $(0.82 \pm 0.07 \mathrm{~cm})$ and in Control $(0.85 \pm 0.01 \mathrm{~cm})$ (Fig. 2).

On day 65, microprofiles in Control showed a 0.27$\mathrm{cm}$ separation between the oxic and sulfidic zones. The $\mathrm{pH}$ profile showed a small maximum close to the sediment-water interface and a minimum in proximity to the sulfidic horizon. In the Marenzelleria treatment, oxygen penetrated down to $1.06 \pm 0.03 \mathrm{~cm}$ (Fig. 1). The sulfidic horizon and the $\mathrm{pH}$ minimum deepened to approximately $1.53 \pm 0.04 \mathrm{~cm}$ indicating the development of an anoxic sulfide-free zone approximately $0.5 \mathrm{~cm}$ thick. In the Monoporeia treatment, the OPD remained stable compared to day 13; however, the anoxic sulfide-free zone had expanded to a thickness of $1.3 \mathrm{~cm}$. In all mesocosms, the sulfidic horizons significantly moved deeper with time $(p<0.001$; Table 2$)$ and at day 65 they were situated at $1.13 \pm 0.02 \mathrm{~cm}, 1.53 \pm 0.04 \mathrm{~cm}$ and $2.12 \pm 0.02 \mathrm{~cm}$ depth 

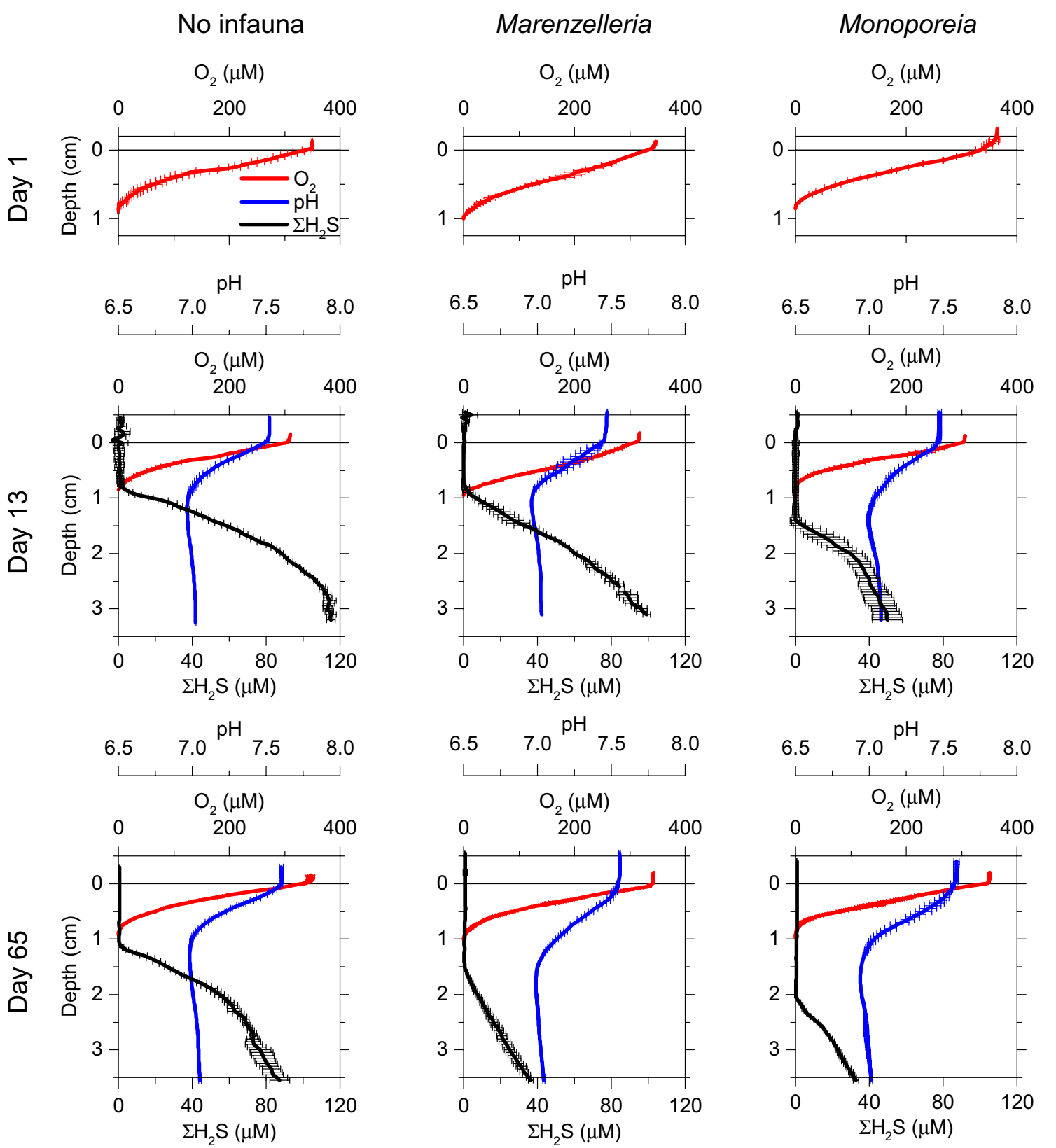

Fig. 1 Sediment microprofiles in the three mesocosms. Oxygen (red), $\mathrm{pH}$ (blue) and $\mathrm{H}_{2} \mathrm{~S}$ (black) lines indicate sediment microprofiles carried out inside (from left to right) control mesocosm, mesocosm amended with Marenzelleria arctia and mesocosm amended with

in Control, Marenzelleria and Monoporeia, respectively (Fig. 2). Throughout the course of the experiment, the sulfidic horizon of Monoporeia was significantly deeper than in Control $(p<0.001)$ and Marenzelleria $(p<0.001)$ (Table 2). Marenzelleria was significantly deeper than Control too $(p=0.016)$ (Table 2).
Monoporeia affinis. Bold lines indicate average microprofiles, while error bars represent standard error of the mean $(n=3-4)$. Horizontal black lines corresponding to $0 \mathrm{~cm}$ depth indicate the sediment-water interface

\section{Sulfide fluxes}

The calculated sulfide fluxes only identify the diffusional transport of sulfide, omitting his advective component, which is an intrinsic characteristic of bioturbated sediments. Thus, sulfide fluxes should be considered representative of 


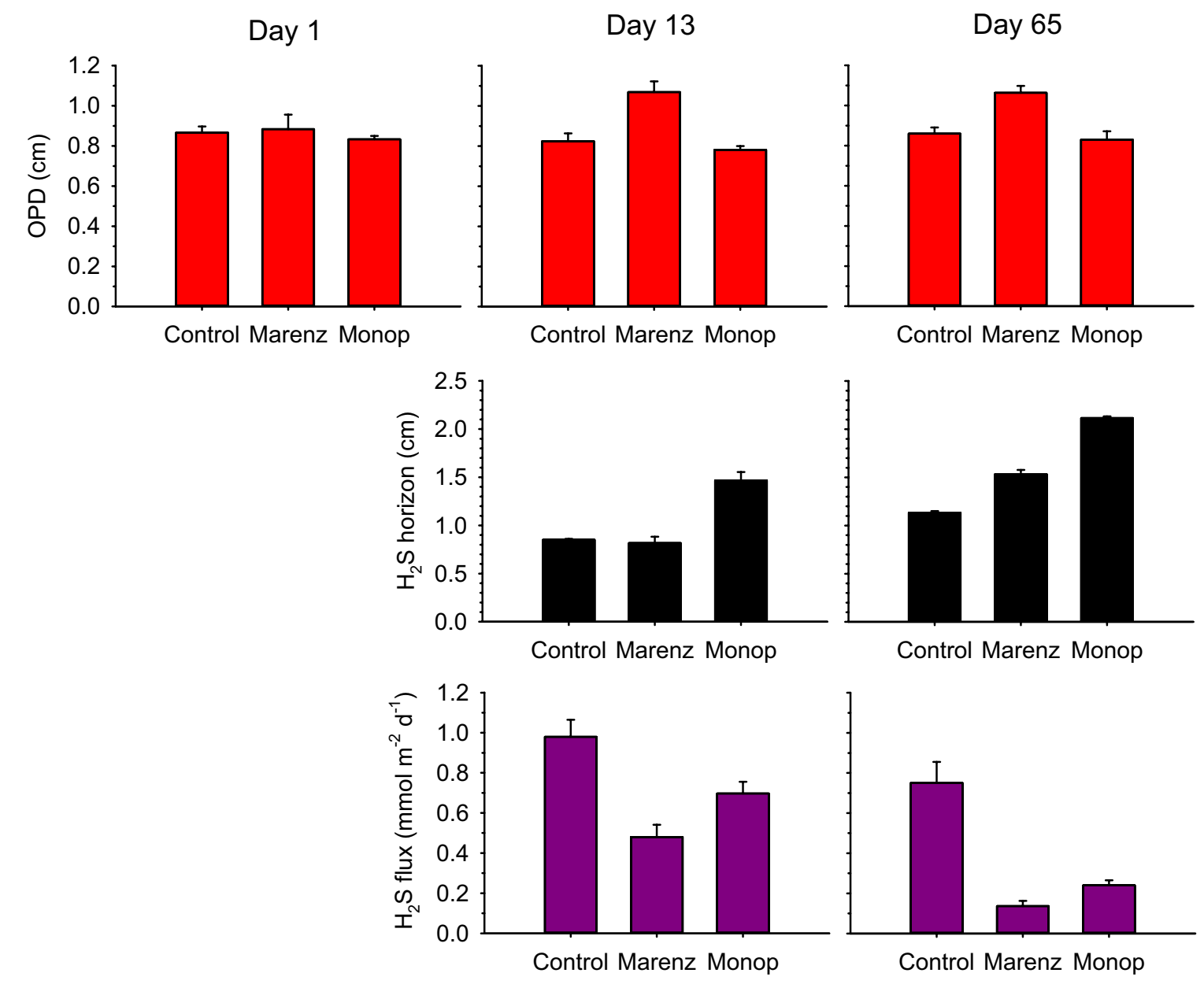

Fig. 2 Summary of the measured oxygen penetration depths (OPDs), depth of the sulfide horizon and diffusive sulfide fluxes in the sediment. For each day of measurement, from left to right: Control=control mesocosm; Marenz $=$ mesocosm amended with Marenzelle- ria arctia; Monop=mesocosm amended with Monoporeia affinis. Colored bars indicate average values and error bars represent standard error of the mean $(n=3-4)$
Table 1 Summary of the results of the two-way repeated measures ANOVA performed to test the effect of factors Day (Day 13 and Day 65) and Treatment (Control, Marenzelleria, Monoporeia) on dependent variables $(\mathrm{OPD}=$ oxygen penetration depth; sulfidic horizon; sulfide flux)

\begin{tabular}{lllllrr}
\hline Dependent variable & Factor & DF & SS & MS & $F$ & $p$ \\
\hline OPD & Day & 2 & 4.638 & 2.319 & 0.9 & 0.467 \\
& Treatment & 2 & 4.545 & 2.272 & 0.8 & 0.496 \\
& Day $\times$ treatment & 4 & 11.21 & 2.802 & 1.0 & 0.445 \\
Sulfidic horizon & Day & 1 & 1.361 & 1.361 & 1666.8 & $<0.001$ \\
& Treatment & 2 & 2.108 & 1.054 & 167.6 & $<0.001$ \\
& Day $\times$ treatment & 2 & 0.163 & 0.0817 & 5.5 & 0.070 \\
Sulfide flux & Day & 1 & 0.53 & 0.53 & 345.6 & 0.003 \\
& Treatment & 2 & 0.986 & 0.493 & 41.9 & 0.002 \\
& Day $\times$ treatment & 2 & 0.0386 & 0.0193 & 3.1 & 0.154 \\
\hline
\end{tabular}

After 13 days of incubation, the diffusive flux of sulfide in the sulfidic horizon was $51 \%$ and $29 \%$ lower in the Marenzelleria and Monoporeia treatments, respectively, compared to Control (Fig. 2). Sulfide fluxes were $0.48 \pm 0.06 \mathrm{mmol} \mathrm{m}^{-2}$ day $^{-1}$ in Marenzelleria, $0.70 \pm 0.06 \mathrm{mmol} \mathrm{m}^{-2}$ day $^{-1}$ in 
Table 2 Summary of pairwise multiple comparison procedures (Holm-Sidak method)

\begin{tabular}{|c|c|c|c|c|c|c|c|c|c|}
\hline \multirow{2}{*}{$\begin{array}{l}\text { Comparisons } \\
\text { for factor }\end{array}$} & \multirow[t]{2}{*}{ Comparison } & \multicolumn{4}{|c|}{ Sulfidic horizon } & \multicolumn{4}{|l|}{ Sulfide flux } \\
\hline & & Diff Means & $t$ & $p$ & $p<0.05$ & Diff Means & $t$ & $p$ & $p<0.05$ \\
\hline Time & Day 13 vs. Day 65 & 0.550 & 40.827 & $<0.001$ & Yes & 0.343 & 18.591 & 0.003 & Yes \\
\hline \multirow[t]{3}{*}{ Treatment } & Marenzelleria vs. Monoporeia & 0.617 & 13.469 & $<0.001$ & Yes & 0.160 & 2.554 & 0.063 & No \\
\hline & Marenzelleria vs. Control & 0.183 & 4.004 & 0.016 & Yes & 0.557 & 8.888 & 0.003 & Yes \\
\hline & Control vs. Monoporeia & 0.800 & 17.473 & $<0.001$ & Yes & 0.397 & 6.334 & 0.006 & Yes \\
\hline
\end{tabular}

Overall significance level $=0.05$

Monoporeia, and $0.98 \pm 0.09 \mathrm{mmol} \mathrm{m}^{-2}$ day $^{-1}$ in Control (Fig. 2).

On day 65 , the sulfide flux in the control was $23 \%$ lower compared to day 13 . However, the difference between the faunated treatments and the control expanded even further, and was $82 \%$ and $68 \%$ lower in the Marenzelleria and Monoporeia treatments, respectively, compared to Control. Fluxes were still lower in Marenzelleria $\left(0.13 \pm 0.03 \mathrm{mmol} \mathrm{m}^{-2}\right.$ day $\left.^{-1}\right)$ and in Monoporeia $\left(0.24 \pm 0.03 \mathrm{mmol} \mathrm{m}^{-2}\right.$ day $\left.^{-1}\right)$ than in Control $\left(0.75 \pm 0.11 \mathrm{mmol} \mathrm{m}^{-2} \mathrm{day}^{-1}\right)$. Throughout the course of the experiment, there was no significant difference in fluxes between Monoporeia and Marenzelleria $(p=0.063)$, but both Marenzelleria $(p=0.003)$ and Monoporeia $(p=0.006)$ were significantly lower than Control (Table 2).

\section{Discussion}

More than thirty oxygen profiles were carried out in this study and most of them in visibly bioturbated sediment. However, we did not record any burrow sign as oxygen concentration anomalies in our treatments, which is interesting to note. Our observations are in line with those of Karlson et al. (2005) who worked on a similar setting with recently oxygenated and colonized sediment, showing that the amphipod Monoporeia affinis is mainly living in the top $2 \mathrm{~cm}$ of the sediment. Here burrows cannot consolidate because of the non-cohesive nature of the sediment, which is characterized by a very high water content $(92 \%)$ and porosity $(0.97)$. The stability of the oxygen penetration depth in the $M$. affinis treatment aligns with a previous study by Tuominen et al. (1999) showing no significant increase in the oxygen penetration in highly porous $(0.95)$ sediment colonized by $M$. affinis compared to bare sediment. These results together indicate that the colonization of previously hypoxic sediments by $M$. affinis does not expand the oxic portion of the sediment. We cannot exclude, however, that this species also renders the surficial sediment organic matter more reactive and degradable by digging and reworking the very top part of the sediment (Karlson et al. 2005), and may favor the contact between organic particles and meiofauna and microorganisms.

Contrary to $M$. affinis, the invasive polychaete $M$. arctia makes consolidated burrows and permanently lives inside the sediment (Renz and Forster 2013; Quintana et al. 2018). Genetic analyses demonstrated three sibling species of Marenzelleria coexist in the Baltic Sea, namely M. arctia, M. neglecta and M. viridis (Blank et al. 2008; Renz and Forster 2013). We did not apply genetic tools to identify the Marenzelleria species, but three lines of evidence indicate that our mesocosm was virtually exclusively colonized by $M$. arctia. First, in the sampling location, $M$. viridis has never been reported, whereas $M$. neglecta has been found only sporadically (Bastrop and Blank 2006; Blank et al. 2008; Ekeroth et al. 2016a). Second, the relatively shallow burrows (extending to $6-7 \mathrm{~cm}$ depth) were $U$ shaped, which is a typical signature of $M$. arctia bioturbation (Quintana et al. 2018). Third, M. arctia is generally the sole species found at deep Baltic Sea sites (below $20 \mathrm{~m}$ ) (Kauppi et al. 2018b). This is important to note as recent studies have highlighted that $M$. arctia has different bioirrigation activity compared to its sibling species and thus may affect porewater profiles differently (Renz and Forster 2013, 2014; Quintana et al. 2018).

A previous study using shallow well-oxidized muddy sediments showed that $M$. arctia has higher burrow ventilation and irrigation efficiencies compared to its two siblings (Quintana et al. 2018). The high irrigation activity by $M$. arctia may cause enhanced nonlocal transport of oxygen increasing, in turn, benthic phosphate retention (Quintana et al. 2018). A companion study, which worked on the same setup as the one used here (i.e., previously anoxic Baltic Sea deep sediments), showed that $M$. arctia had much lower irrigation potential compared to findings by Quintana et al. (2018), leading to insignificant effects for phosphate retention (Ekeroth et al. 2016a). The weak effect of M. arctia on phosphate along with mobilization of reduced compounds (e.g., ammonium) was recently confirmed (Kauppi et al. 2018a). Our results, which indicate that $M$. arctia did not substantially increase the oxygenation of the sediment, are in line with those from these previous studies (Ekeroth et al. 2016a; Kauppi et al. 2018a), and corroborate the idea that after sediment oxygenation and recolonization, $M$. 
arctia maintains low activity at least in the first weeks of colonization.

As it was described previously, $M$. arctia by living and burrowing several centimeters inside the sediment substantially increases rates of total benthic oxygen uptake (Bonaglia et al. 2013). Also in the M. arctia treatment we did not record any burrow sign as oxygen concentration subsurface peaks. We cannot exclude that we might have profiled too far away from the burrows. However, considering that our sediment was visibly bioturbated - as the one in Fig. 1 of Norkko et al. (2012) — we rather believe that $M$. arctia burrows were generally not well ventilated and that oxygen was absent most of the time. This is supported by the fact that most of the enhanced benthic oxygen uptake by $M$. arctia activity is actually due to polychaete respiration (68\%), while the contribution of new burrow structures is minor (32\%) (Bonaglia et al. 2013).

About 2 weeks after the experiment started, the oxygen and sulfide profiles slightly overlapped indicating that sulfide was primarily oxidized by oxygen diffusing from the overlying water in the fauna-free sediment. By the end of the experiment, $M$. arctia decreased porewater sulfide pool by $>50 \%$. Our observation contrasts with previous studies indicating that $M$. arctia temporally enhances sulfide concentrations in the porewater because its high irrigation potential mobilizes both oxidized and reduced compounds in sediment burrows (Bonaglia et al. 2013; Quintana et al. 2018). It is interesting to note that our results, valid for $M$. arctia, are apparently in contrast with those from the sibling species $M$. viridis, which can burrow much deeper $(>20 \mathrm{~cm})$ and double sedimentary sulfate reduction rates in coastal sediments (Kristensen et al. 2011). Moreover, most of the studies on $M$. viridis have been carried out with sandy sediments, which are preferred by this larger species (Kristensen et al. 2011; Renz and Forster 2013; Quintana et al. 2018), while studies on $M$. arctia have been conducted almost exclusively on soft mud (Hietanen et al. 2007; Bonaglia et al. 2013; Quintana et al. 2018). Thus, different results may also be explained by the different degree of sediment cohesiveness.

Two weeks after colonization, Marenzelleria did not significantly extend the suboxic zone-the zone devoid of both oxygen and sulfide-while in the sediment with Monoporeia a distinct separation between the oxic and sulfidic zones could already be measured. Two months after sediment colonization, there were $0.5-\mathrm{cm}$ - and $1.5-\mathrm{cm}$-thick suboxic zones in the Marenzelleria and Monoporeia treatments, respectively. We exclude that internal sulfide detoxification by the animals played a significant role, and we mainly attribute these expansions of the suboxic zone to the bioturbation activity of the animals. M. arctia was not actively burrowing during our measurements, but its activity was mainly limited to radial diffusion (bioirrigation), which mobilizes oxygen, sulfate and sulfide (Bonaglia et al. 2013; Quintana et al. 2018). This might have enhanced remineralizationincluding sulfate reduction-locally and have had an effect, although not significant, on oxygen penetration. The effect of sulfide re-oxidation by this species is probably ineffective when oxygenation is only a transient phenomenon (up to a few weeks), but may become significant after long-term oxygenation events ( 2 months on). M. affinis actively mixes the upper sediment layer and creates sulfide-free "pockets" inside the sediment (Modig and Olafsson 2001). Its activity resulted very effective in voiding the upper sediment from hydrogen sulfide both after short- and long-term oxygenation. Following oxygenation, the stronger sulfide removal induced by $M$. affinis might thus lead to faster recolonization by aerobic bacteria and opportunistic polychaetes as earlier suggested for a whole-fjord oxygenation experiment (Stigebrandt et al. 2015).

The $0.5-1.5-\mathrm{cm}$-thick suboxic zone induced by macrofauna bioturbation indicates that the sediment mixing by the amphipod and sediment irrigation by the polychaete activated $\mathrm{Fe}, \mathrm{Mn}$ and nitrate cycling and with them the oxidation of acid volatile sulfide (AVS) and iron sulfide minerals $\left(\mathrm{FeS}_{2}\right)$. In the Monoporeia treatment, the $\mathrm{pH}$ minimum coincided with the depth where sulfide started appearing and not with the depth where $\mathrm{O}_{2}$ disappeared. This might be symptomatic of the intense processes of re-oxidation of reduced metabolites and sulfide minerals (Boudreau and Canfield 1988), and indicate that the dominant process generating the $\mathrm{pH}$ minimum was sulfide oxidation and not aerobic respiration. In the presence of $M$. affinis, due to the larger separation between the $\mathrm{O}_{2}$ and $\mathrm{H}_{2} \mathrm{~S}$ zones, the upward free sulfide was oxidized with something else than oxygen, likely Fe and/or Mn oxyhydroxides, or nitrate. Thus, M. affinis bioturbation activity may have facilitated the formation and recycling of Fe and/or Mn oxyhydroxides, which then likely generated this gap between the oxygenated and sulfidic zones. Mesocosm experiments with previously anoxic sediments collected in a 100-m-deep Baltic fjord showed indeed that especially Mn plays an important role in porewater geochemistry and that reduction of Mn oxides may account for a large fraction of carbon mineralization in these seasonally hypoxic, deep coastal sediments (Bonaglia et al. 2013; Danielsson et al. 2018). Besides oxidation of minerals by physical mixing, bioturbation by the amphipods might have favored oxidative nitrogen cycling processes such as nitrification (Ekeroth et al. 2016a), which in turn might promote nitrogen removal through denitrification (Tuominen et al. 1999).

Other organisms that can contribute to the separation between the oxic and sulfidic zones are sulfide-oxidizing bacteria, i.e., Beggiatoaceae and cable bacteria (filamentous Desulfobulbaceae). Beggiatoaceae can store nitrate intracellularly and migrate vertically in the sediment to 
oxidize sulfide (Sayama et al. 2005), whereas cable bacteria can couple sulfide oxidation with oxygen or nitrate reduction over distances of centimeters by conducting electric currents (Pfeffer et al. 2012; Marzocchi et al. 2014). Beggiatoaceae and cable bacteria both have been reported from Baltic sediment overlain by transient oxic water (Yucel et al. 2017; Marzocchi et al. 2018). However, these organisms leave characteristic $\mathrm{pH}$ signatures in the sediment (Sayama et al. 2005; Nielsen et al. 2010). Due to the systematic absence of such $\mathrm{pH}$ signatures in our profiles as well as the absence of a clear suboxic zone in the control mesocosm, we exclude that Beggiatoaceae and cable bacteria played a significant role in the buildup of the separation between the oxic and sulfidic zones observed in our mesocosms.

An earlier experiment carried out with similar deep Baltic Sea sediments showed that $M$. affinis actively dig into sulfidic sediments, perhaps in search for food (Modig and Olafsson 2001). Except for the short time following algal blooms, Baltic Sea sediments are limited in terms of fresh food for macrofauna (Elmgren 1978). When phytoplankton and other organic detritus are not available as main food source, $M$. affinis tend to feed on bacteria, meiofauna and juveniles of the tellinid bivalve Macoma balthica (Elmgren 1978; Goedkoop and Johnson 1994; Ejdung et al. 2000). Thus, it can be that the amphipods were actively seeking for bacteria and meiofaunal organisms, mostly nematodes, that have been shown to live in hypoxic and anoxic Baltic sediments (Elmgren 1975). Furthermore, we cannot exclude that the reactive organic carbon pool was getting more and more depleted in our mesocosms (Ekeroth et al. 2016a), due to a limited import of fresh organic particles with the inflowing water, and as a consequence the main product of heterotrophic anaerobic metabolism-hydrogen sulfidewas reduced. The decrease in sulfide fluxes from day 13 to day 65 in bare sediment confirms a general decrease in sediment metabolism (e.g., sulfate reduction activity) with time. The simple decrease in sulfate reduction alone is not expected to generate a suboxic zone, which is rather diagnostic of the activation of mineral cycling via sediment mixing possibly by meiofaunal nematodes. It is indeed well known that nematodes can survive anoxia (anoxybiosis) and even sulfidic conditions (thiobiosis) for years in aquatic sediments as reviewed by Tahseen (2012). However, the organisms that generated the suboxic zone in the control treatment did it to an extent that was significantly minor compared to the larger separation in the macrofauna treatments. We recommend that the influence of meiofauna bioturbation on sulfide oxidation be addressed in future experiments.

\section{Conclusions}

Baltic Sea bottom water and surface sediments are affected by temporal or long-term hypoxia and anoxia, which make large parts of the central Baltic azoic. Long-term studies of Baltic Sea water quality conditions show significant improvements in the eutrophication status in recent decades (Andersen et al. 2017). When oxygenation happens, macrofauna recolonize these previously anoxic sediments causing drastic effects in porewater geochemistry and benthic fluxes of solutes (Norkko et al. 2012; Bonaglia et al. 2013; Ekeroth et al. 2016a, b; Danielsson et al. 2018). Our results show that colonization by macrofauna did not significantly increase oxygen penetration inside the sediment. We ran our experiment for more than 2 months to understand the longterm effects of macrofauna bioturbation on porewater sulfide distribution. On the one hand, long-term responses could be appreciated, but on the other hand, the animals might have reduced their metabolism with time as input of fresh organic material became more limiting. However, our results show that $M$. affinis increased the volume of oxidized, sulfide-free sediments by $87 \%$ compared to the Control treatment and by $38 \%$ compared to the $M$. arctia treatment, respectively. When upscaled to a hectare of sea floor, it results that $M$. affinis leads to an increase of $98 \mathrm{~m}^{3}$ and $58 \mathrm{~m}^{3}$ of oxidized, sulfide-free sediment compared to non-bioturbated sediment and $M$. arctia, respectively. Thus, an important implication is that epifaunal amphipods colonizing previously hypoxic and anoxic sediments would make the sediment surface more hospitable for other benthic organisms that benefit from sulfide-free conditions. In contrast, we showed that $M$. arctia does not lead to a similarly clear sulfide removal. These latter results are in line with those of several modeling and experimental studies indicating that $M$. arctia (1) might increase the upward advective flux of anoxic and sulfidic waters; (2) stimulate sulfate reduction rates; (3) regenerate pools of reduced metabolites (Bonaglia et al. 2013; Danielsson et al. 2018; Kauppi et al. 2018a; Quintana et al. 2018). We conclude that colonization of previously anoxic sediment by the amphipod M. affinis stimulates the oxidation of a larger volume of sediment and is more favorable for the establishment of later colonizers than colonization by the invasive polychaete $M$. arctia.

Acknowledgements Open access funding provided by Stockholm University. Financial support for this study was provided by the Swedish Environmental Protection Agency through a grant to POJH for the BOX project, the Formas Strategic Research Grant 2009-813 and the Baltic Sea Centre, Stockholm University, who supported the experimental work conducted by SB through an Askö grant. At the moment of the manuscript writing and submission, SB was supported by the Swedish Research Council Formas (Grant no. 2017-01513). SB and UM were additionally supported by project INBALANCE funded by the European Social Fund (Grant no. 09.3.3-LMT-K-712-01-0069). We thank the staff at the Askö Laboratory for support during mesocosm 
setup and the crew of R/V Fyrbyggaren for assistance at sea. This manuscript was improved through feedback from three anonymous reviewers, who are kindly acknowledged.

\section{Compliance with ethical standards}

Conflict of interest The authors declare that they have no conflict of interest.

Ethical approval All applicable national and/or institutional guidelines for the use of collection material were followed. Only invertebrates were used in this study.

Open Access This article is distributed under the terms of the Creative Commons Attribution 4.0 International License (http://creativeco mmons.org/licenses/by/4.0/), which permits unrestricted use, distribution, and reproduction in any medium, provided you give appropriate credit to the original author(s) and the source, provide a link to the Creative Commons license, and indicate if changes were made.

\section{References}

Aller R (1982) The effects of macrobenthos on chemical properties of marine sediment and overlying water. In: McCall P, Tevesz MS (eds) Animal-sediment relations. Springer, US, pp 53-102

Aller RC (1994) Bioturbation and remineralization of sedimentary organic matter: effects of redox oscillation. Chem Geol 114:331345. https://doi.org/10.1016/0009-2541(94)90062-0

Andersen JH, Carstensen J, Conley DJ, Dromph K, Fleming-Lehtinen V, Gustafsson BG, Josefson AB, Norkko A, Villnäs A, Murray C (2017) Long-term temporal and spatial trends in eutrophication status of the Baltic Sea. Biol Rev 92:135-149

Andrews D, Bennett A (1981) Measurements of diffusivity near the sediment-water interface with a fine-scale resistivity probe. Geochim Cosmochim Acta 45:2169-2175. https://doi. org/10.1016/0016-7037(81)90069-7

Bastrop R, Blank M (2006) Multiple invasions-a polychaete genus enters the Baltic Sea. Biol Invas 8:1195-1200

Berner RA (1984) Sedimentary pyrite formation: an update. Geochim Cosmochim Acta 48:605-615

Björk M, Gilek M (1996) Uptake and elimination of 14 C-phenanthrene by the blue mussel Mytilus edulis L. at different algal concentrations. Bull Environ Contam Toxicol 56:151-158

Blank M, Laine AO, Juerss K, Bastrop R (2008) Molecular identification key based on PCR/RFLP for three polychaete sibling species of the genus Marenzelleria, and the species' current distribution in the Baltic Sea. Helgol Mar Res 62:129-141. https://doi. org/10.1007/s10152-007-0081-8

Blomqvist S, Lundgren L (1996) A benthic sled for sampling soft bottoms. Helgoländer Meeresuntersuchungen 50:453

Blomqvist S, Ekeroth N, Elmgren R, Hall POJ (2015) Long overdue improvement of box corer sampling. Mar Ecol Prog Ser 538:1321. https://doi.org/10.3354/meps 11405

Bonaglia S, Bartoli M, Gunnarsson JS, Rahm L, Raymond C, Svensson O, Shakeri Yekta S, Brüchert V (2013) Effect of reoxygenation and Marenzelleria spp. bioturbation on Baltic Sea sediment metabolism. Mar Ecol Prog Ser 482:43-55. https://doi. org/10.3354/meps10232

Boudreau BP, Canfield DE (1988) A provisional diagenetic model for $\mathrm{pH}$ in anoxic porewaters: application to the FOAM site. J Mar Res 46:429-455
Breitburg D, Levin LA, Oschlies A, Grégoire M, Chavez FP, Conley DJ, Garçon V, Gilbert D, Gutiérrez D, Isensee K, Jacinto GS, Limburg KE, Montes I, Naqvi SWA, Pitcher GC, Rabalais NN, Roman MR, Rose KA, Seibel BA, Telszewski M, Yasuhara M, Zhang J (2018) Declining oxygen in the global ocean and coastal waters. Science 359:eaam7240. https://doi.org/10.1126/science.aam7240

Brüchert V, Jørgensen BB, Neumann K, Riechmann D, Schlösser M, Schulz H (2003) Regulation of bacterial sulfate reduction and hydrogen sulfide fluxes in the central Namibian coastal upwelling zone. Geochim Cosmochim Acta 67:4505-4518

Canfield DE (1989) Sulfate reduction and oxic respiration in marine sediments: implications for organic carbon preservation in euxinic environments. Deep Sea Res Pt A Oceanogr Res Pap 36:121-138. https://doi.org/10.1016/0198-0149(89)90022-8

Cline JD (1969) Spectrophotometric determination of hydrogen sulfide in natural waters. Limnol Oceanogr 14:454-458

Danielsson Å, Rahm L, Brüchert V, Bonaglia S, Raymond C, Svensson O, Yekta SS, Reyier H, Gunnarsson JS (2018) Effects of re-oxygenation and bioturbation by the polychaete Marenzelleria arctia on phosphorus, iron and manganese dynamics in Baltic Sea sediments. Boreal Environ Res 23:15-28

Diaz RJ (2001) Overview of hypoxia around the world. J Environ Qual 30:275-281

Diaz RJ, Rosenberg R (1995) Marine benthic hypoxia: a review of its ecological effects and the behavioural responses of benthic macrofauna. Oceanogr Mar Biol Annu Rev 33:245-303

Dyrssen D, Kremling K (1990) Increasing hydrogen sulfide concentration and trace metal behavior in the anoxic Baltic waters. Mar Chem 30:193-204

Ejdung G, Byrén L, Elmgren R (2000) Benthic predator-prey interactions: evidence that adult Monoporeia affinis (Amphipoda) eat postlarval Macoma balthica (Bivalvia). J Exp Mar Biol Ecol 253:243-251

Ekeroth N, Blomqvist S, Hall PO (2016a) Nutrient fluxes from reduced Baltic Sea sediment: effects of oxygenation and macrobenthos. Mar Ecol Prog Ser 544:77-92

Ekeroth N, Kononets M, Walve J, Blomqvist S, Hall POJ (2016b) Effects of oxygen on recycling of biogenic elements from sediments of a stratified coastal Baltic Sea basin. J Mar Syst 154B:206-219. https://doi.org/10.1016/j.jmarsys.2015.10.005

Elmgren R (1975) Benthic meiofauna as indicator of oxygen conditions in the northern Baltic proper. Merentutkimuslait Julk/Havsforskningsinst Skr 239:265-271

Elmgren R (1978) Structure and dynamics of Baltic benthos communities, with particular reference to the relationship between macroand meiofauna. Verlag nicht ermittelbar, Genk

Gilbert F, Stora G, Bertrand JC (1996) In situ bioturbation and hydrocarbon fate in an experimental contaminated Mediterranean coastal ecosystem. Chemosphere 33:1449-1458. https://doi. org/10.1016/0045-6535(96)00283-4

Glibert P, Burkholder J (2006) The complex relationships between increases in fertilization of the earth, coastal eutrophication and proliferation of harmful algal blooms Ecology of harmful algae. Springer, Berlin, pp 341-354

Goedkoop W, Johnson RK (1994) Exploitation of sediment bacterial carbon by juveniles of the amphipod Monoporeia affinis. Freshw Biol 32:553-563

Hahlbeck E, Arndt C, Schiedek D (2000) Sulphide detoxification in Hediste diversicolor and Marenzelleria viridis, two dominant polychaete worms within the shallow coastal waters of the southern Baltic Sea. Comp Biochem Physiol B Biochem Mol Biol 125:457-471. https://doi.org/10.1016/S0305-0491(00)00158-9

Hietanen S, Laine AO, Lukkari K (2007) The complex effects of the invasive polychaetes Marenzelleria spp. on benthic 
nutrient dynamics. J Exp Mar Biol Ecol 352:89-102. https://doi. org/10.1016/j.jembe.2007.07.018

Hill C, Elmgren R (1987) Vertical distribution in the sediment in the co-occurring benthic amphipods Pontoporeia affinis and P. femorata. Oikos 1:221-229

Howarth RW (1984) The ecological significance of sulfur in the energy dynamics of salt marsh and coastal marine sediments. Biogeochemistry 1:5-27

Jahn A, Theede H (1997) Different degrees of tolerance to hydrogen sulphide in populations of Macoma balthica (Bivalvia, Tellinidae). Mar Ecol Prog Ser 154:185-196

Jeroschewski P, Steuckart C, Kühl M (1996) An amperometric microsensor for the determination of $\mathrm{H} 2 \mathrm{~S}$ in aquatic environments. AnaCh 68:4351-4357. https://doi.org/10.1021/ac960091b

Jørgensen BB (1982) Mineralization of organic matter in the sea bed-the role of sulphate reduction. Nature 296:643-645. https ://doi.org/10.1038/296643a0

Jørgensen BB, Böttcher ME, Lüschen H, Neretin LN, Volkov II (2004) Anaerobic methane oxidation and a deep H 2 S sink generate isotopically heavy sulfides in Black Sea sediments. Geochim Cosmochim Acta 68:2095-2118

Karlson K, Hulth S, Ringdahl K, Rosenberg R (2005) Experimental recolonisation of Baltic Sea reduced sediments: survival of benthic macrofauna and effects on nutrient cycling. Mar Ecol Prog Ser 294:35-49. https://doi.org/10.3354/meps294035

Kauppi L, Norkko A, Norkko J (2015) Large-scale species invasion into a low-diversity system: spatial and temporal distribution of the invasive polychaetes Marenzelleria spp. in the Baltic Sea. Biol Invas 17:2055-2074. https://doi.org/10.1007/s1053 0-015-0860-0

Kauppi L, Bernard G, Bastrop R, Norkko A, Norkko J (2018a) Increasing densities of an invasive polychaete enhance bioturbation with variable effects on solute fluxes. Sci Rep 8:7619

Kauppi L, Norkko A, Norkko J (2018b) Seasonal population dynamics of the invasive polychaete genus Marenzelleria spp. in contrasting soft-sediment habitats. J Sea Res 131:46-60. https:// doi.org/10.1016/j.seares.2017.10.005

Keeling RF, Körtzinger A, Gruber N (2010) Ocean deoxygenation in a warming world. Annu Rev Mar Sci 2:199-229. https://doi. org/10.1146/annurev.marine.010908.163855

Kristensen E (2000) Organic matter diagenesis at the oxic/anoxic interface in coastal marine sediments, with emphasis on the role of burrowing animals life at interfaces and under extreme conditions. Springer, Berlin, pp 1-24

Kristensen E, Blackburn T (1987) The fate of organic carbon and nitrogen in experimental marine sediment systems: influence of bioturbation and anoxia. J Mar Res 45:231-257

Kristensen E, Hansen T, Delefosse M, Banta GT, Quintana CO (2011) Contrasting effects of the polychaetes Marenzelleria viridis and Nereis diversicolor on benthic metabolism and solute transport in sandy coastal sediment. Mar Ecol Prog Ser 425:125-139. https://doi.org/10.3354/meps09007

Kristensen E, Penha-Lopes G, Delefosse M, Valdemarsen T, Quintana CO, Banta GT (2012) What is bioturbation? The need for a precise definition for fauna in aquatic sciences. Mar Ecol Prog Ser 446:285-302. https://doi.org/10.3354/meps09506

Marzocchi U, Trojan D, Larsen S, Meyer RL, Revsbech NP, Schramm A, Nielsen LP, Risgaard-Petersen N (2014) Electric coupling between distant nitrate reduction and sulfide oxidation in marine sediment. ISME J 8:1682-1690. https://doi.org/10.1038/ ismej.2014.19

Marzocchi U, Bonaglia S, van de Velde S, Hall POJ, Schramm A, Risgaard-Petersen N, Meysman FJR (2018) Transient bottom water oxygenation creates a niche for cable bacteria in long-term anoxic sediments of the Eastern Gotland Basin. Environ Microbiol. https://doi.org/10.1111/1462-2920.14349

Middelburg JJ, Vlug T, Jaco F, van der Nat WA (1993) Organic matter mineralization in marine systems. Glob Planet Change 8:47-58. https://doi.org/10.1016/0921-8181(93)90062-S

Modig H, Olafsson E (2001) Survival and bioturbation of the amphipod Monoporeia affinis in sulphide-rich sediments. Mar Biol 138:87-92

Nascimento FJA, Näslund J, Elmgren R (2012) Meiofauna enhances organic matter mineralization in soft sediment ecosystems. Limnol Oceanogr 57:338-346. https://doi.org/10.4319/ lo.2012.57.1.0338

Nicholls P (1975) The effect of sulphide on cytochrome aa3. Isosteric and allosteric shifts of the reduced alpha-peak. AcBB 396:2435. https://doi.org/10.1016/0005-2728(75)90186-3

Nielsen LP, Risgaard-Petersen N, Fossing H, Christensen PB, Sayama M (2010) Electric currents couple spatially separated biogeochemical processes in marine sediment. Nature 463:10711074. https://doi.org/10.1038/nature08790

Norkko J, Reed DC, Timmermann K, Norkko A, Gustafsson BG, Bonsdorff E, Slomp CP, Carstensen J, Conley DJ (2012) A welcome can of worms? Hypoxia mitigation by an invasive species. Glob Change Biol 18:422-434. https://doi.org/10.11 11/j.1365-2486.2011.02513.x

Pfeffer C, Larsen S, Song J, Dong MD, Besenbacher F, Meyer RL, Kjeldsen KU, Schreiber L, Gorby YA, El-Naggar MY, Leung KM, Schramm A, Risgaard-Petersen N, Nielsen LP (2012) Filamentous bacteria transport electrons over centimetre distances. Nature 491:218-221. https://doi.org/10.1038/Nature11586

Quintana CO, Raymond C, Nascimento FJA, Bonaglia S, Forster S, Gunnarsson JS, Kristensen E (2018) Functional performance of three invasive Marenzelleria species under contrasting ecological conditions within the Baltic Sea. Estuaries Coasts 41:17661781. https://doi.org/10.1007/s12237-018-0376-9

Renz JR, Forster S (2013) Are similar worms different? A comparative tracer study on bioturbation in the three sibling species Marenzelleria arctia, $M$. viridis, and $M$. neglecta from the Baltic Sea. Limnol Oceanogr 58:2046-2058. https://doi. org/10.4319/lo.2013.58.6.2046

Renz JR, Forster S (2014) Effects of bioirrigation by the three sibling species of Marenzelleria spp. on solute fluxes and porewater nutrient profiles. Mar Ecol Prog Ser 505:145-159

Revsbech NP, Jørgensen BB (1986) Microelectrodes: their use in microbial ecology. Springer, Berlin, pp 293-352

Sandberg-Kilpi E, Vismann B, Hagerman L (1999) Tolerance of the Baltic amphipod Monoporeia affinis to hypoxia, anoxia and hydrogen sulfide. Ophelia 50:61-68

Sayama M, Risgaard-Petersen N, Nielsen LP, Fossing H, Christensen $\mathrm{PB}$ (2005) Impact of bacterial $\mathrm{NO}_{3}$-transport on sediment biogeochemistry. Appl Environ Microbiol 71:7575-7577

Stigebrandt A, Liljebladh B, de Brabandere L, Forth M, Granmo A, Hall P, Hammar J, Hansson D, Kononets M, Magnusson M, Norén F, Rahm L, Treusch A, Viktorsson L (2015) An experiment with forced oxygenation of the deepwater of the anoxic By Fjord, Western Sweden. Ambio 44:42-54. https:// doi.org/10.1007/s13280-014-0524-9

Tahseen Q (2012) Nematodes in aquatic environments: adaptations and survival strategies. Biodiver J 3:13-40

Tuominen L, Mäkelä K, Lehtonen KK, Haahti H, Hietanen S, Kuparinen J (1999) Nutrient fluxes, porewater profiles and denitrification in sediment influenced by algal sedimentation and bioturbation by Monoporeia affinis. Estuar Coast Shelf Sci 49:83-97. https://doi.org/10.1006/ecss.1999.0492

Ullman WJ, Aller RC (1982) Diffusion-coefficients in nearshore marine-sediments. Limnol Oceanogr 27:552-556 
Vaquer-Sunyer R, Duarte CM (2010) Sulfide exposure accelerates hypoxia-driven mortalit. Limnol Oceanogr 55:1075-1082

Villnäs A, Norkko A (2011) Benthic diversity gradients and shifting baselines: implications for assessing environmental status. Ecol Appl 21:2172-2186

Völkel S, Grieshaber MK (1992) Mechanisms of sulphide tolerance in the peanut worm, Sipunculus nudus (Sipunculidae) and in the lugworm, Arenicola marina (Polychaeta). J Comp Physiol B 162:469-477. https://doi.org/10.1007/bf00258971

Völkel S, Grieshaber MK (1995) Sulfide tolerance in marine invertebrates. In: Heisler N (ed) Mechanisms of systemic regulation: acid-base regulation, ion-transfer and metabolism. Springer, Berlin, pp 233-257
Weissberger EJ, Coiro LL, Davey EW (2009) Effects of hypoxia on animal burrow construction and consequent effects on sediment redox profiles. J Exp Mar Biol Ecol 371:60-67. https:// doi.org/10.1016/j.jembe.2009.01.005

Yucel M, Sommer S, Dale AW, Pfannkuche O (2017) Microbial sulfide filter along a benthic redox gradient in the Eastern Gotland Basin, Baltic Sea. Front Microbiol. https://doi.org/10.3389/ fmicb.2017.00169

Publisher's Note Springer Nature remains neutral with regard to jurisdictional claims in published maps and institutional affiliations. 